\title{
K Brezposelnost, priložnost za spremembe
}

\author{
Aleksa Gajš̌k Krajnc
}

\section{$V$ hitro spreminjajočem se okolju si človekovega razvoja ne moremo predstavljati} brez stalnega obnavljanja, spreminjanja in pridobivanja znanja. Pregovor, »kar si se naučil, to znaš«, že dolgo ne drži več, pa ne le zaradi zastaranja ali izgube naučenega, temveč zaradi nuje po posodabljanju obstoječega ter osvajanju novega.

Ljudje smo pri tem različni: eni so bolj dovzetni za spremembe in željni novosti, drugi so manj pripravljeni za sprejemanje izzivov in premagovanje težav, povezanih $\mathrm{z}$ njimi.

Velik del današnje odrasle generacije je bil vzgojen v prepričanju, da pridobljeno znanje zadošča za preživetje ter da sta poklic in zaposlitev pridobljena za zmeraj. In s takšnim prepričanjem so se znašli mnogi, ki so izgubili delo, med naraščajočim številom brezposelnih v Sloveniji. Doživeli so spremembo, pretres, jezo, razočaranje. Mnogi so tudi predolgo vztrajali pri iskanju zaposlitve za obstoječe znanje ter že pridobljen poklic, ki morda ni konkurenčen na trgu delovne sile, znanje pa je preskromno in zastarelo.

Kako pomagati omenjene$\mathrm{mu}$ potencialu delovne sile in kako ga spodbuditi k razmišljanju, da tudi zanj velja pravilo vseživljenjskega učenja, ki lahko pomaga tako pri reševanju osebnih stisk brezposelnosti kot pri večanju možnosti za pridobitev novega dela in osebno rast.

V podjetju Racio iz Celja se zavedamo, da se lahko ljudje razvijajo samo, če so se pripravljeni razvijati. Vendar je ljudem lažje, če jim okolje pomaga, in morda je dovolj, da le spodbudi spečo pripravljenost za samorazvoj.

Tako smo razvili in skupaj z Območno enoto Republiškega zavoda za zaposlovanje (RZZ) v Celju izpeljali motivacijsko izborne programe »Če hočem, sem lahko aktiven « za brezposelne. V 60 izvedb, imenovanih tudi programi »out-reach «, se je vključilo 1051 oseb, ki so pred tem svojo 6 do 24 mesecev trajajočo brezposelnost preživljale razmeroma pasivno - vztrajajoč pri čakanju in nespremenjenih poklicnih ciljih.

\section{"Če hočem, sem lahkro aktiven«}

»Če hočem, sem lahko aktiven« je motivacijsko izborni program, katerega cilj je vplivati na udeležence, da se soočijo z brezposelnostjo ter ob zunanji spodbudi začno dejavnosti, ki pospešujejo možnosti za razrešitev njihovega problema ter za primeren samorazvoj.

Ciljna skupina so bile osebe, ki so bile brezposelne 6 mesecev ali več, niso bile »težje zaposljive« in niso bile vključene v druge

\section{Prikaz objektivno merljivih rezultatov programa}

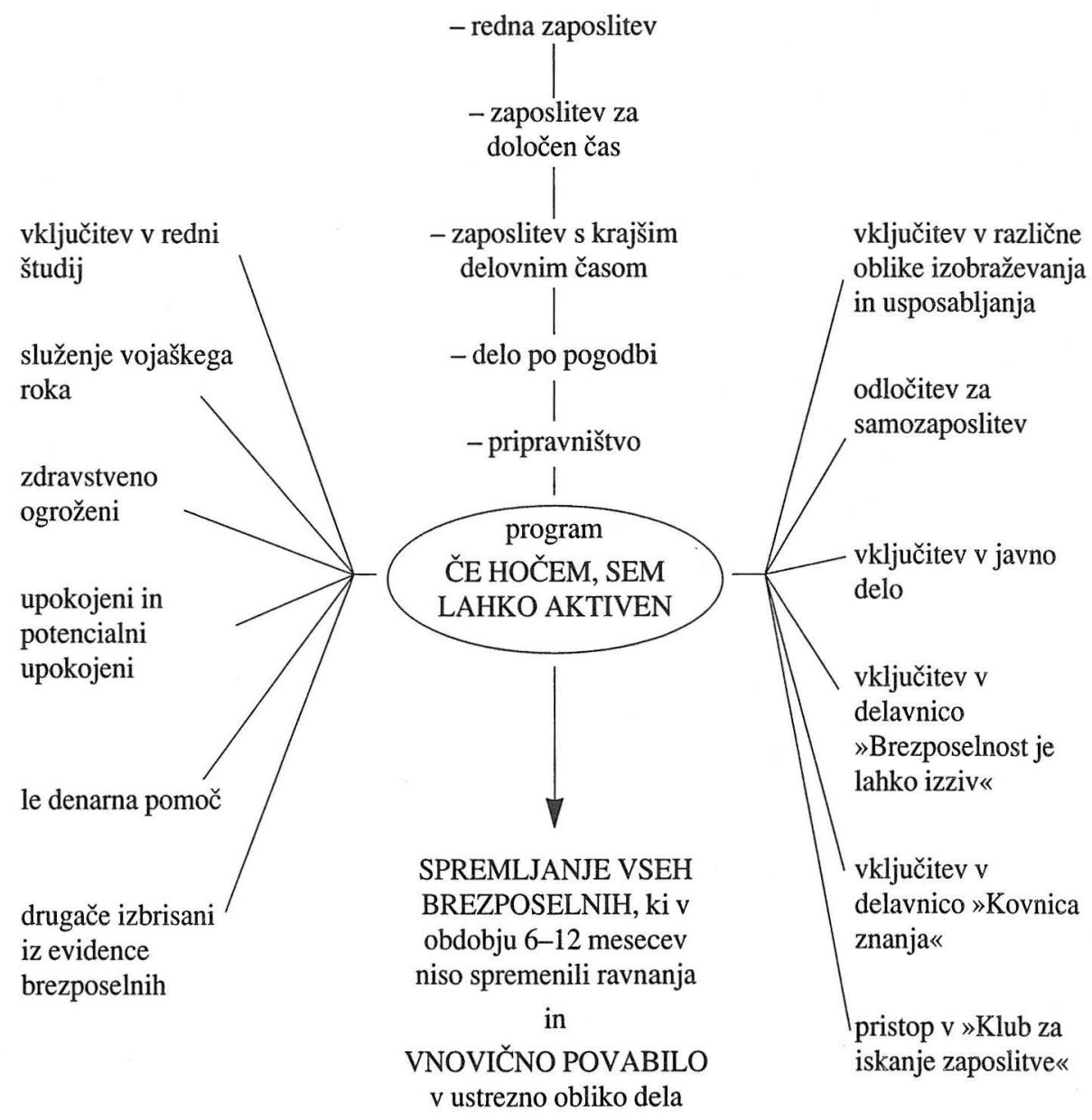




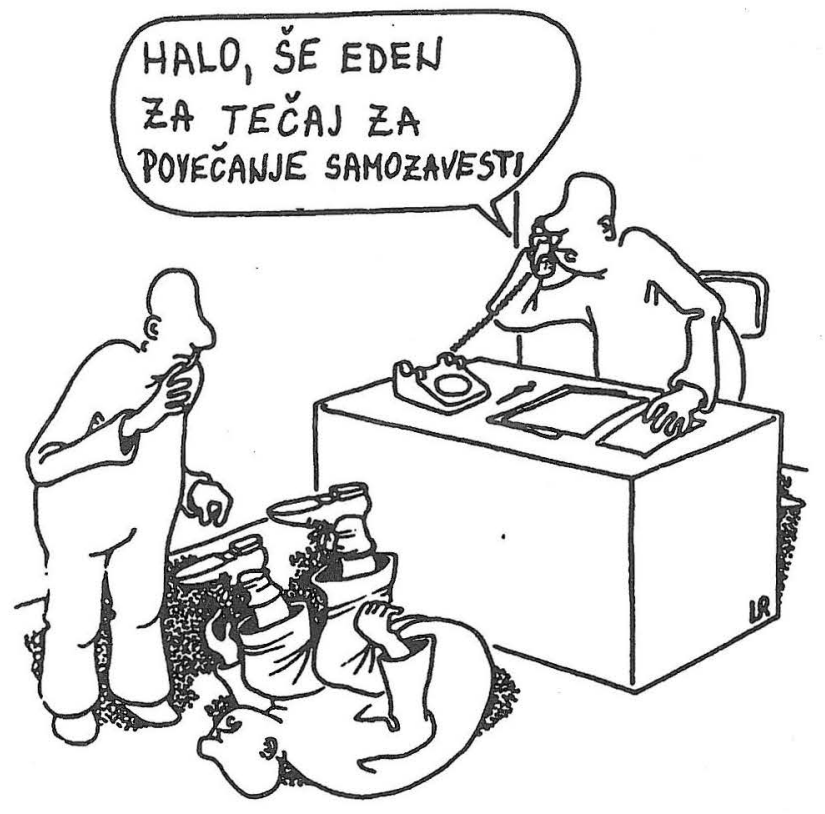

programe aktivne politike zaposlovanja. Skupina šteje do 25 udeležencev in priporočljivo je, da je oblikovana homogeno glede na starost in izobrazbo.

Program je zasnovan na razvojnem modelu pomoči, na redefiniciji problema brezposelnosti ter socioemocionalni opori.

- Začne se s predstavitvijo udeležencev in z opisom njihovih občutij ter dejavnosti $v$ času brezposelnosti. $Z$ individualno predstavitvijo vsakega udeleženca se že v začetku programa ustvari ozračje za sproščeno skupinsko delo, pri katerem se ves čas izmenjujejo medsebojni vplivi udeležencev in izvajalcev programa.

Sledi izčrpna predstavitev položaja na trgu delovne sile v Sloveniji, po potrebi dopolnjena $\mathrm{z}$ družbenimi in gospodarskimi spremembami ter konkretna problematika brezposelnosti na območnem trgu. Udeleženci dobijo celovit uvid v svoje pravice in obveznosti ter se seznanijo s ponudbo programov in ukrepov aktivne politike zaposlovanja, ki jih ponuja konkretna območna enota kot pomoč ali spodbudo.

- Udeleženci nato izpolnijo standardizirano anketo RZZ, v kateri predstavijo svoje formalne podatke in trenutni položaj ter že nakažejo lastno razmišljanje, želje, interese ter predstave o mogočih načinih reševanja brezposelnosti.

Izvajalec programa v odmoru pregleda izpolnjene ankete ter njihovim rezultatom prilagodi nadaljnje delo v skupini.

- Sledi obsežnejši vsebinski sklop, namenjen redefiniranju problema brezposelnosti in socioemocionalni opori. Udeležencem, ki so bili večinoma "pasivno čakajoči«, se brezposelnost predstavi kot obdobje možnosti in priložnosti. Predavanje in skupinsko delo je usmerjeno k večanju samozavesti, vrnitvi pozitivne samopodobe ter $\mathrm{k}$ spodbujanju povezanosti z okoljem. Predstavljene so vsebine:

- proces spreminjanja;

- doživljanje in obvladovanje stresnih položajev;

- model posameznikovega uspeha, ki omogoča kompenzacije med zmožnostmi, znanjem, motiviranostjo in osebnostnimi lastnostmi;

- ugotavljanje lastnih prednosti in slabosti ter odkrivanje priložnosti in nevarnosti v okolju;

- postavljanje osebnih ciljev;

- razvoj kariere, premiki navzgor in navzdol.
Vsebine se prilagajajo izobrazbeni in starostni strukturi udeležencev, njihovi zmožnosti dojemanja ter njihovim potrebam.

$\mathrm{V}$ zadnjem delu programa se glede na interese udeležencev oblikujejo skupine $\mathrm{z}$ različnimi cilji in rešitvami. Vsak udeleženec se na podlagi skupinskega in posamičnega dela $\mathrm{z}$ izvajalci programa odloči za prvi korak, ki ga bo napravil po programu. Koraki so različni. Gre za dejavnosti, ki segajo od brezposelne osebe, ki ne želi in ne potrebuje spremembe, do brezposelne osebe, ki je aktivirala svoj potencial ter si zadala svoj prvi delovni cilj.

Pri programu se uporabljajo različne metode in tehnike ter pripomočki (individualni nastop, predavanje, dajanje informacij, pisna ponudba programov, anketa, skupinsko delo in poročanje, možganska nevihta (brainstorming), analiza SWOT, individualno svetovanje, prijavnice za različne programe...). Zelo pomembno je, da so udeleženci dejavno vpeti v dogajanje, sprejeti pri izvajalcu (po komunikacijskih pravilih so partnerji) ter da so spodbujeni k sproščenemu razmišljanju.

Program traja 6 do 8 pedagoških ur, odvisno od udeležencev: bolj poglobljeno in daljše delo je potrebno $\mathrm{z}$ udeleženci nad $\mathrm{V}$. stopnjo strokovne izobrazbe, pa tudi s starejšimi brezposelnimi osebami.

Izvajalci so svetovalci Območne enote RZZ ter predstavniki zunanje institucije, v našem primeru podjetja Racio iz Celja.

\section{Evalvacija programa}

Da bi ocenili smotrnost in koristnost programov, smo po izvedbi opravili študijo, ki sta jo sofinancirala ministrstvo za delo, družino in socialne zadeve ter republiški zavod za zaposlovanje. Preverili smo hipotezo, da brezposelni, ki se udeležijo programa »Če hočem, sem lahko aktiven«, postanejo dejavnejši pri reševanju problemov svoje zaposlitve. Kot aktivnost smo definirali kakršno koli obliko dejavnosti brezposelne osebe, ki to odvrača od »čakanja doma in na rešitev od drugih, od zunaj«. To pomeni povečano pripravljenost za iskanje dela, za izobraževanje ter za vključevanje $v$ različne programe $R Z Z$.

Učinke programa smo ugotavljali dvakrat:

1. Neposredno po končanem programu (izražen interes, želja, namere udeležencev).

Ugotovitve: * skoraj polovica udeleženih se želi izobraževati oziroma usposabljati, kar širi zaposlitvene možnosti,

* slaba tretjina je nezainteresiranih; potrebno je nadaljne svetovalno delo,

* petina brezposelnih je brez končne odločitve; cilji so postavljeni, vendar potrebujejo čas in zorenje za njihovo uresničitev.

2. Leto dni po končanem programu (ugotavljanje dejanske aktivnosti ali ravnanja udeležencev).

Ugotovitve: * dobra polovica udeleženih je spremenila svoj položaj; od tega se jih je več kot polovica izpisala iz evidence brezposelnih, drugi pa so vključeni v pripravo - različne programe usposabljanja RZZ,

* slaba polovica svojega položaja ni spremenila.

Interpretacija ugotovitev je zahtevna. Omogoča nam le primerjavo med objektivno merljivimi podatki, procesa razmišljanja in odločanja pri posameznikih pa nam ne odkriva. Zato ne moremo trditi, da je spremembe $\mathrm{v}$ vedenju udeležencev povzročil zgolj program, prav tako pa tega ne moremo zanikati.

Upoštevajoč podatek evalvacijskih študij, po katerih 30-od- 


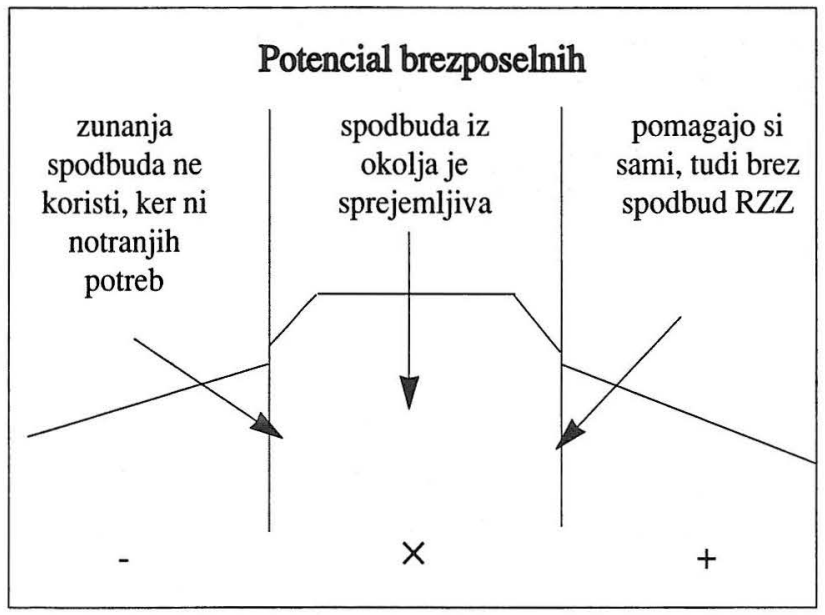

stotna realizacija (izplen) pomeni dober rezultat, $\mathrm{v}$ našem primeru pa je bila ta 54-odstotna, ter dejstvo, da je populacija brezposelnih sestavni del Gaussove krivulje normalne porazdelitve, smo potrdili hipotezo, da program spodbudi udeležence oziroma poveča njihovo pripravljenost za iskanje rešitev.

Po teoriji dovzetnosti ljudi za spremembe so to vzorci vedenja:

\begin{tabular}{|c|c|c|}
\hline $\begin{array}{c}\text { NAJ ONI } \\
\text { (naj uredi država) }\end{array}$ & $\begin{array}{c}\text { DAJ TI } \\
\text { (pomagajte mi) }\end{array}$ & $\begin{array}{c}\text { BOM JAZ } \\
\text { (sam bom) }\end{array}$ \\
\hline
\end{tabular}

Uspešnost programa so potrdila in dopolnila tudi mnenja svetovalcev - izvajalcev programov, ki skupinsko-individualni pristop ocenjujejo kot racionalizacijo dela, za brezposelne pa kot svetovalno storitev višje kakovosti.

\section{Sklepna misel}

Res je, kot smo zapisali v uvodu, da se človek lahko razvija le, če sam hoče. A res je tudi, da je večini ljudi dobrodošla »pomoč« od zunaj, ki spodbudi njihovo dejavnost. Dokaz za to je, da je več kot polovica udeležencev motivacijsko izbornega programa »Če hočem, sem lahko aktiven« spremenila svoje vedenje.

Ljudi, ki jim 6 mesecev, leto ali celo več ni uspelo spremeniti statusa, je med brezposelnimi v Sloveniji več kot 60 odstotkov. Zato je spodbujanje in izobraževanje tako obsežnega dela populacije odraslih nujno in ga je smotrno uveljavljati.

mag. Aleksa Gajšek Krajnc

diplomirana psihologinja in nosilka projekta v podjetju

Racio Celje, d.o.o.

\section{Liperaturm}

Raziskovalni projekt: Evalvacija animacijsko izbornih programov za brezposelne in postavitev modela, 1995, Racio Celje, Celje 